\title{
Short-Term Variations in Microbiological and Chemical Parameters*
}

\author{
L.-A. Meyer-Reil, M. Bölter, G. Liebezeit and W. Schramm \\ Institut für Meereskunde an der Universität Kiel, Düsternbrooker Weg 20, D-2300 Kiel 1, Federal Republic of Germany
}

\begin{abstract}
At three Baltic-Sea stations, short-term variations were monitored of a number of microbiological and chemical parameters. At two of these stations (Kämpinge, Sweden; south-eastern Baltic Sea) uniform, individual water bodies were sampled at short intervals. Here, distinct patterns or rhythms could be demonstrated in the variation of microbiological and chemical parameters, obviously reflecting different ecological situations. In contrast, at the third station in the Kiel Fjord, no indication could be found of a distinct common denominator for variations in microbiological and/or chemical parameters; possible patterns of fluctuations may have been masked by changing water bodies. The causes for the fluctuation patterns observed at the two stations remain unclear There is some indication that the material cycle in natural waters is governed by strong short-term fluctuations or even rhythms of microbiological and chemical parameters; these require further investigation.
\end{abstract}

\section{INTRODUCTION}

As has been documented in Volume I of 'Marine Ecology' (Gunkel, 1970, 1972; Oppenheimer, 1970; MacLeod, 1971; Rheinheimer, 1971, 1972; Morita, 1972; ZoBell, 1972) microorganisms react relatively quickly to changes in their environment. This is particularly true for quantitative and qualitative changes in the nutrients available. Since bacteria play an important role in the mineralization process and the foodweb (e.g. Sorokin, 1978), short-term variations in bacterial activity can greatly and quickly influence the material cycle in oceans and coastal waters.

Most investigations of microbiological parameters are based on samples taken at weekly or monthly intervals. Despite the fact that the crucial role of microorganisms in the marine environment is well known, microbiologists tend to neglect short-term investigations. However, only activity rates determined at short intervals under in situ conditions can provide information on the dynamics of an ecological system (e.g. Kinne, 1978).

This paper presents observations on short-term variations in microbiological and chemical parameters measured at three stations located in the brackish

\footnotetext{
- Publication No. 243 of the 'Joint Research Program' at Kiel University (Sonderforschungsbereich 95 der Deutschen Forschungsgemeinschaft)
}

Baltic Sea. Special emphasis is laid on interactions between microbiological and chemical parameters.

\section{MATERIAL AND METHODS}

Based on sterile glass-flask samples taken from surface waters ( 1 to $2 \mathrm{~m}$ water depth), short-term variations in microbiological and chemical parameters have been compared at three different stations. During a joint research program at Kämpinge (Baltic Sea, Sweden; June 4, 1977), a shallow water body was sampled at 2 - $h$ intervals over a 12 -h cycle. The sampled water body was overlying an eel-grass community enclosed in a plastic bag (approximately 1,000 l capacity). During a second joint research program (BOSEX 1977. Baltic Open Sea Experiment; September 9/10, 1977), samples were taken every 6 h over a 24 -h cycle from the south-eastern Baltic Sea (Station $56^{\circ} 06^{\prime} \mathrm{N} 18^{\circ} 44^{\prime} \mathrm{E}$ ). A third sample series was collected every $3 \mathrm{~h}$ during a 24-h cycle from the innermost Kiel Fjord (Baltic Sea, FR of Germany; Station 'Institutsanleger'; November 29/30, 1977).

Bacterial numbers and number of cells actively metabolizing glucose were determined by a combined autoradiography/epifluorescence microscopy technique, recently described by Meyer-Reil (1978a). Bacterial biomass was analysed based on size fractionation of individual cells (Meyer-Reil, 1977). For determining 
the number of colony-forming units, the spread-plate technique was applied, using a medium consisting of Bacto-peptone $(0.5 \%)$, yeast-extract $(0.1 \%)$ and Bactoagar $(1.6 \%)$ in natural-aged seawater (diluted to $10 \%$ S). The plates were incubated over 14 days at in situ temperatures.

Uptake studies were carried out by the tracer technique using ${ }^{14} \mathrm{C}$-glucose (U) and ${ }^{14} \mathrm{C}$-fructose (U) (specific activity 150 and $200 \mathrm{mCi} / \mathrm{mmol}$, respectively; New England Nuclear). $10-\mathrm{ml}$ samples were incubated in glass bottles (Sovirel $50-\mathrm{ml}$ capacity) with $50 \mu \mathrm{l}$ of ${ }^{14} \mathrm{C}$-glucose $(0.014 \mu \mathrm{g})$ and $50 \mu \mathrm{l}$ of ${ }^{14} \mathrm{C}$-fructose $(0.023 \mu \mathrm{g})$, respectively. Duplicate samples and a blank (fixed with $30 \mu \mathrm{l}$ of concentrated formalin) were run for different incubation times $(0.5,1,1.5,2,3 \mathrm{~h})$ at temperatures within 1 to $2 \mathrm{C}^{\circ}$ of in situ temperatures. Duplicate sets were used to measure incorporation and respiration (for details compare Meyer-Reil et al., 1978). Radioactivity was determined in a liquid scintillation counter (Betazint 5000; Berthold and Frieseke) using a scintillation medium consisting of toluene and Omnifluor $\left(5.5 \mathrm{~g} \mathrm{l}^{-1}\right)$.

${ }^{14} \mathrm{C}$-uptake rates $\left(\mu \mathrm{g}{ }^{14} \mathrm{C}\right.$-glucose or fructose $\left.\mathrm{l}^{-1} \mathrm{~h}^{-1}\right)$ were calculated (no kinetic approach) from the slope of uptake curves determined by linear regression. Gross uptake rates were obtained from the slope of curves calculated for the sum of the amount of labelled solute associated within cells (net uptake) and respired (respiration). Actual uptake rates (flux) resulted from multiplying gross uptake rates with the quotient of the total amount of glucose or fructose present in the sample and the amount of labelled solute added. Turnover times were calculated by dividing substrate concentration by the actual uptake rate. Details of calculations have been described by Meyer-Reil (1978b) and Meyer-Reil et al. (1978).

The concentrations of natural, free dissolved glucose and fructose were measured after electrodialysing and evaporating the samples in a high-sensitivity sugar analyser, run with a single borate buffer system. Details of the actual analytical procedure will appear separately (Dawson and Liebezeit, unpublished). Amino acids were separated by column chromatography (Dawson and Pritchard, 1978). Total free amino acids were measured according to Josefsson (1970).

Dissolved inorganic matter (phosphate, silicate, ammonia, nitrite, nitrate), as well as dissolved organic carbon and particulate organic carbon and nitrogen, have been analysed according to Grasshoff (1976). Salinity and temperature were recorded using portable probes (Yellow Springs Instrument Co., Inc., Yellow Springs, Ohio). Spearmari rank correlation analysis followed Sachs (1974).

\section{RESULTS}

Bacterial numbers and biomass, analysed during a 12 -h period in a body of water overlying an eel-grass community enclosed in a plastic bag (Kämpinge, Baltic Sea; Sweden), followed a distinct pattern. Varying by a factor of 2, number and biomass showed maximum values in the morning and in the evening with minimum values around noon. Dissolved organic carbon (DOC) and total free amino acids (FAA) fluctuated at 4-h intervals. Whereas differences in the concentration of FAA generally comprised a factor of 2 , differences in the concentration of DOC were less pronounced. Generally, individual amino acids (aspartic acid, threonine, serine, glutamic acid, glycine, alanine) reflected the fluctuations of FAA (Fig. 1).
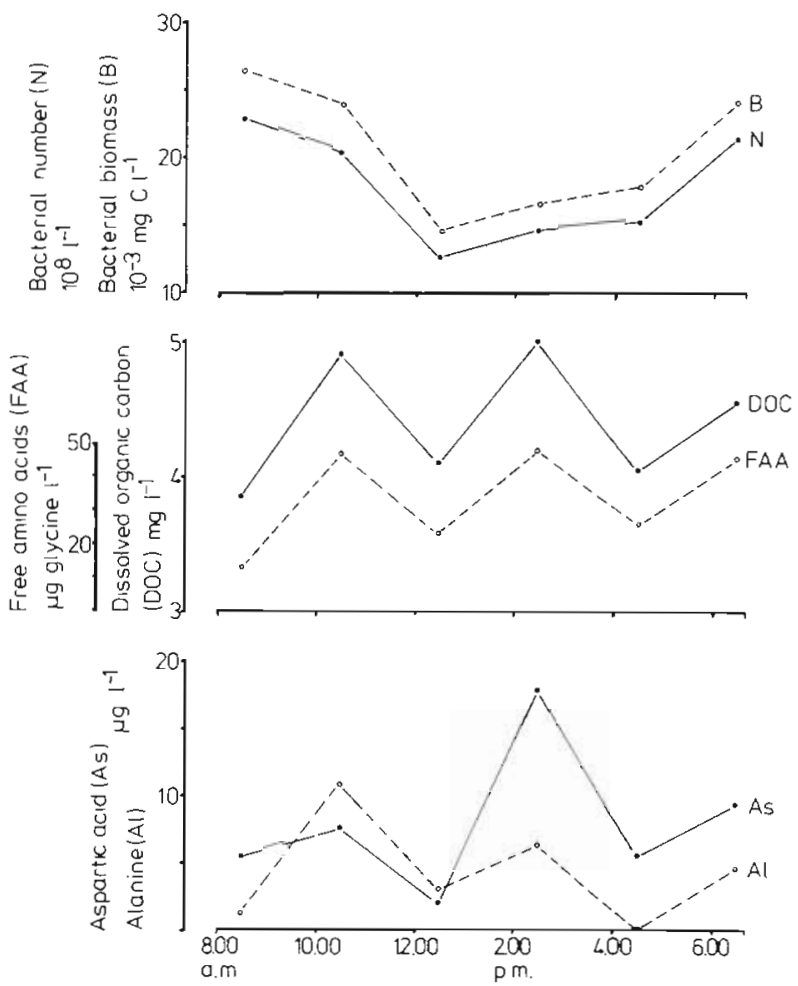

Fig. 1. Diumal variations in microbiological and chemical parameters monitored at Kämpinge (Baltic Sea, Sweden; June 4, 1977)

Among the inorganic nutrients, phosphate revealed a peak (near $30 \mu \mathrm{g}$-at l $\mathrm{l}^{-1}$ ) in the morning and decreased continually during the day. The highest concentrations of ammonia (near $15 \mu \mathrm{g}$-at $\mathrm{l}^{-1}$ ) were measured in the afternoon with low values in the morning and in the evening. Variations in concentrations of both phosphate and ammonia comprised a factor of 2 (Von Wachenfeld, personal communication). Salinity $(7.7-8.0 \% \mathrm{~S})$ and temperature $\left(13-15.5 \mathrm{C}^{\circ}\right)$ remained relatively constant during the observation period. 
Similar curves were obtained for variations in microbiological parameters determined during a $24-\mathrm{h}$ cycle in water samples taken from the station in the south-eastern Baltic Sea (joint research program BOSEX 1977). Colony-forming units, bacterial number and biomass (direct counts), number of cells actively metabolizing glucose (autoradiography/epifluorescence microscopy technique) and actual uptake rates (flux) of glucose and fructose generally increased during the day, reached maximum values in the evening and decreased during the night (Fig. 2). Differences in the number of colony-forming units were relatively small. However, the percentage of pigmented colonies (mainly yellow) decreased considerably during the night (maximum $41 \%$ in the evening, minimum $11 \%$ near midnight). Variations in the number of cells actively metabolizing glucose comprised a factor of 3 . In contrast, differences in the total number of cells and biomass were much less pronounced. The variations in concentration and turnover time of natural free dissol-
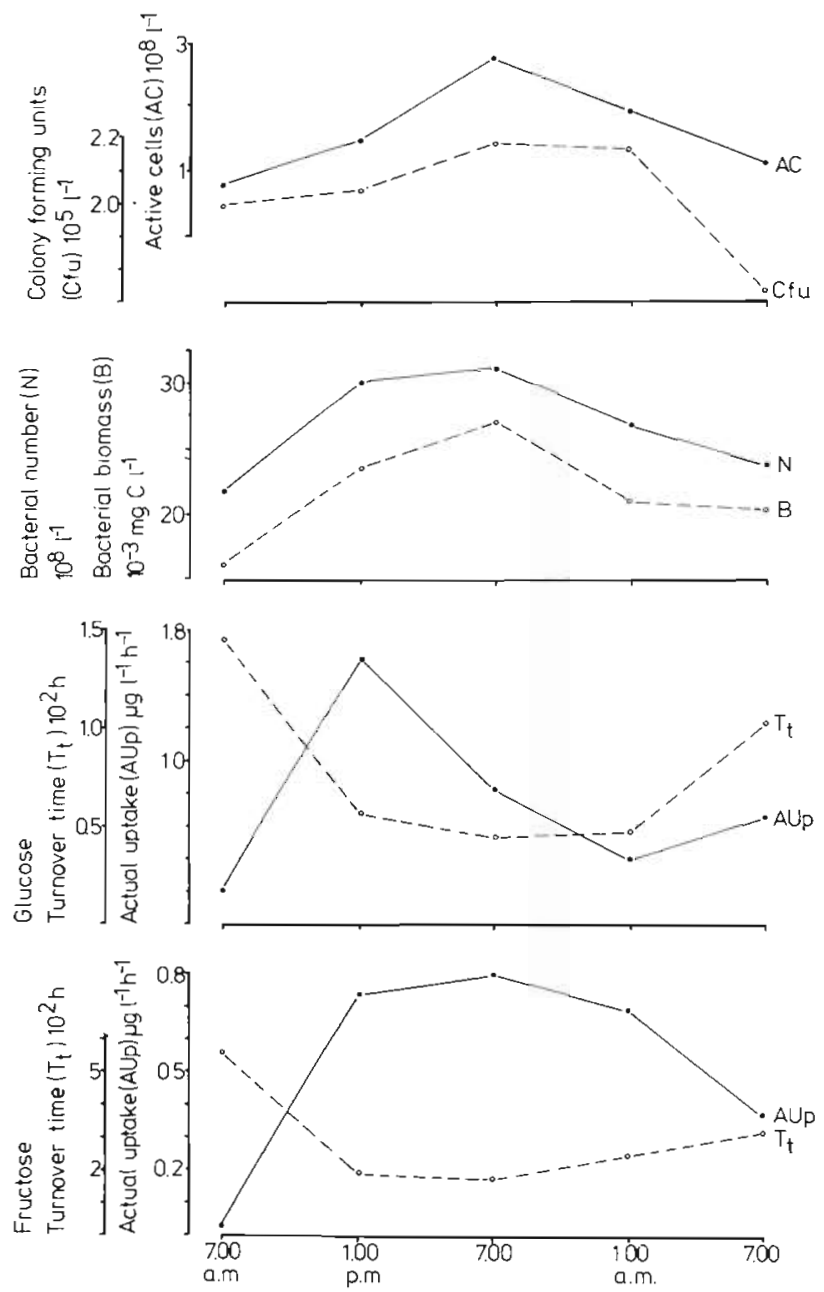

ved glucose and fructose differed from the pattern described above. Generally, variations in the concentration of glucose (between 18.9 and $92.1 \mu \mathrm{g} \mathrm{l}^{-1}$ ) and fructose (between 14.4 and $140 \mu \mathrm{g} \mathrm{l}^{-1}$ ) were similar. However, the time lag between the decrease in the concentration of glucose versus fructose is obvious. Whereas actual uptake rates of glucose (between $2.14 \times 10^{-1}$ and $16.27 \times 10^{-1} \mu \mathrm{g} \mathrm{l}^{-1} \mathrm{~h}^{-1}$ ) generally followed the concentration of glucose, actual uptake rates of fructose (between $0.26 \times 10^{-1}$ and $7.99 \times 10^{-1} \mu \mathrm{g} \mathrm{l}^{-1}$ $\mathrm{h}^{-1}$ ) were more correlated with gross uptake rates of ${ }^{14} \mathrm{C}$-fructose (not shown in the figure). The curves calculated for the variations in turnover time of glucose and fructose turned out to be inversely correlated with the variations obtained for the other microbiological parameters (Fig. 2).

Variations in dissolved and particulate organic carbon and in total free amino acids showed similar curve patterns (Fig. 2). As demonstrated for turnover time, organic parameters were inversely correlated with the microbiological parameters. The variations in individual amino acids differed from the pattern described for the total free amino acids. All amino acids deter-
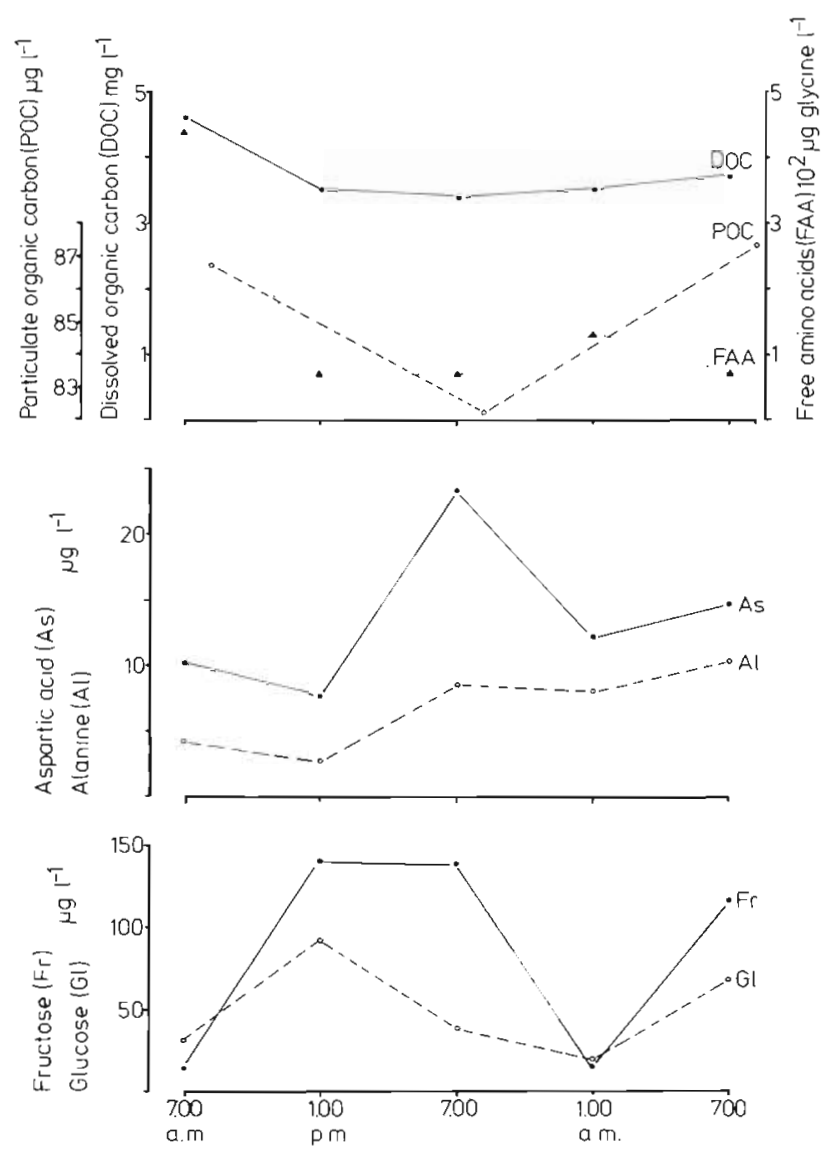

Fig. 2. Diurnal variations in microbiological and chemical parameters monitored in the south-easterm Baltic Sea (Station $56^{\circ} 06^{\prime} \mathrm{N}$ $18^{\circ} 44^{\prime} \mathrm{E}$, BOSEX 1977; September 9/10, 1977) 
mined individually attained minimum values around noon. Maximum concentration values of aspartic acid, glutamic acid, threonine, serine and glycine were obtained in the evening. Only alanine and valine differed from this pattern showing maxima towards the morning of the next day.

The concentration of dissolved inorganic nutrients (phosphate, ammonia, nitrite and nitrate) remained below the significance level. Only silicate was present in measurable concentrations (between 4.5 and $5.8 \mu \mathrm{g}$ $\left.\mathrm{I}^{-1}\right)$. The concentration of chlorophyll $a$ and primary production was relatively low $1.9 \mathrm{mg} \mathrm{m}^{-3}$ and near 30 mg C m-3 $\mathrm{d}^{-1}$, respectively; Knoppers, personal communication). The hydrographical conditions remain ed very constant (salinity: $7.6 \% \mathrm{~S}_{i}$ temperature: $15.0-15.2^{\circ} \mathrm{C}$; oxygen: saturated).
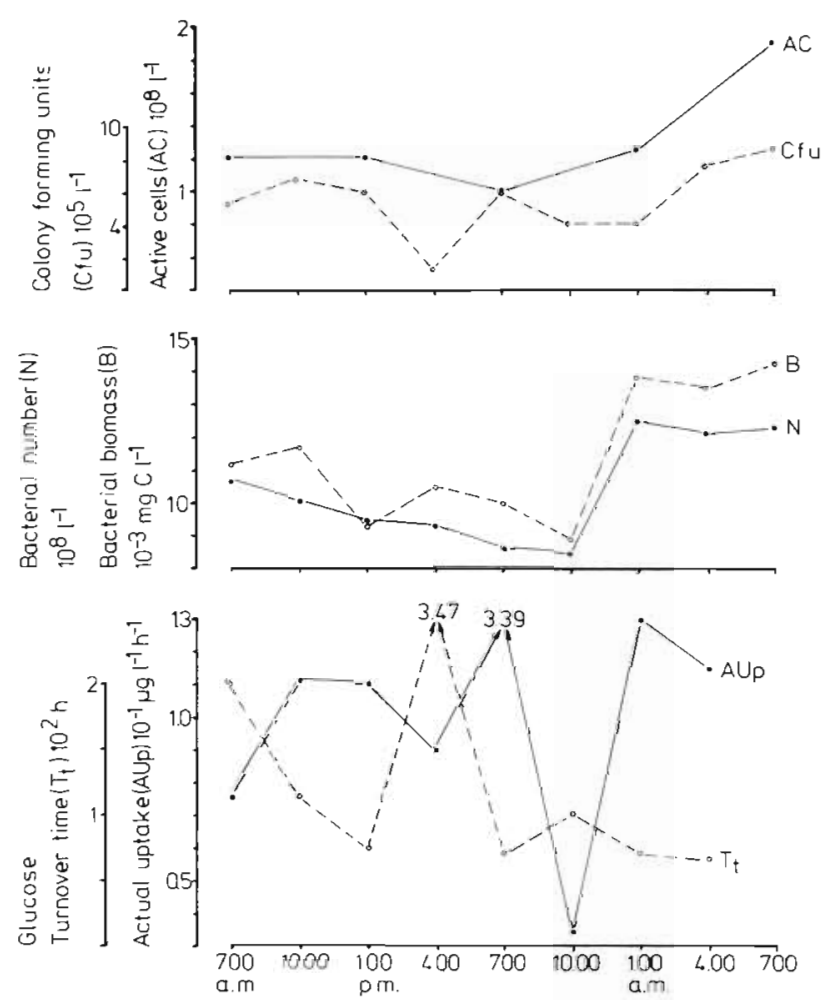

dissolved glucose (between 3.4 and $31.2 \mu \mathrm{g} \mathrm{l}^{-1}$ ) and fructose (between 10.5 and $114 \mu \mathrm{g} \mathrm{l}^{-1}$ ) remained similar. However, the drastic increase in the concentration of fructose towards the end of the observation period was not accompanied by a corresponding increase in glucose concentration. The actual uptake rates of glucose (between $0.34 \times 10^{-1}$ and $3.39 \times 10^{-1} \mu \mathrm{g} \mathrm{l}^{-1} \mathrm{~h}^{-1}$ ) reflected the variations in gross uptake rates of ${ }^{14} \mathrm{C}$ glucose. Actual uptake rates of fructose (between $0.12 \times 10^{-1}$ and $1.04 \times 10^{-1} \mu \mathrm{g} \mathrm{l}^{-1} \mathrm{~h}^{-1}$; not shown in the figures) were more related to variations in fructose concentration. Variations in the turnover time of glucose turned out to be similar to glucose concentration.

Phosphate, silicate, ammonia, nitrite and nitrate varied during the observation period. Differences were recorded in salinity $(20.5-18.5 \%$ S), temperature $\left(6.8-7.4^{\circ} \mathrm{C}\right)$ and oxygen $(11.5-9.2$ p.p.m.).
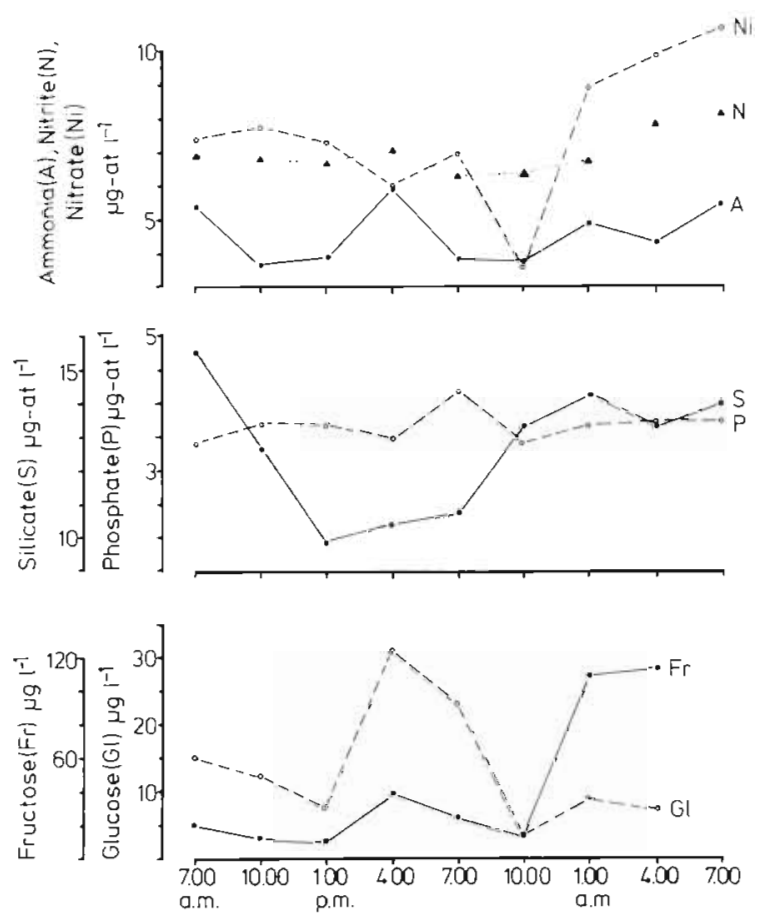

Fig. 3. Diurnal variations in microbiological and chemical parameters monitored in Kiel Fjord (Station 'Institutsanleger'; November 29/30, 1977)

Microbiological and chemical parameters analysed during a 24-h cycle in water samples from the innermost Kiel Fjord (Baltic Sea; FR of Germany) underwent strong variations revealing heterogeneous curve patterns (Fig. 3). Whereas the number of colony-forming units varied by a factor of 6 , variations in total number of cells, biomass and number of cells actively metabolizing glucose were much less pronounced. The latter parameters revealed similar curves. Despite the concentration differences, variations in natural free

\section{DISCUSSION AND CONCLUSIONS}

The variations documented in microbiological and chemical parameters reflect differences in the ecological situation and the uniformity of the water bodies studied.

By enclosing a body of water overlying an eel-grass community in a plastic bag (Kämpinge, Sweden), a uniform water volume was monitored over a 12-h cycle. Dissolved organic carbon, total free dissolved 
amino acids, as well as individual amino acids, fluctuated at 4 -h intervals during the day. This indicates that the release of organic compounds (by primary producers) and their consumption (by heterotrophic organisms) followed a distinct rhythm; the causes of this rhythm are unknown. At least the initiation of the rhythm must have been governed by primary producers. Although also the total number of microorganisms and their biomass followed a distinct pattern, no simple relationship could be found between fluctuations of organic compounds and microbial number or biomass. However, cell numbers do not have to reflect bacterial activity (Meyer-Reil et al., 1978). The variations in inorganic nutrients do not avail themselves for a simple explanation of the pronounced rhythm.

Phosphate concentration decreased continuously during the day, indicating that consumption by far exceeded regeneration. Ammonia accumulated in the afternoon, probably due to high heterotrophic degradation of organic compounds. According to Schramm and Von Wachenfeld (unpublished), inorganic nutrients measured in the water outside the plastic bag followed the same curve patterns; these were maintained over weeks.

The station in the south-eastern Baltic Sea (joint research programm BOSEX 1977) seems to indicate a relatively "simple" system. In the sampling area, a significant influence of land can be excluded. Primary production was low; the concentration of inorganic nutrients remained below the significance level (except for silicate). During the 24 -h observation period, the oceanographic situation was characterized by a uniform, circulating body of water, as demonstrated by floats (Krauss, personal communication). Strong winds caused thorough mixing in the surface layer, thus prohibiting the formation of individual, separated bodies of water.

These observations - together with the constant values of salinity, temperature and oxygen content - led to the conclusion that, during the sampling period, a homogeneous, uniform body of water was monitored. The validity of this conclusion is underlined by the appearance of a distinct pattern of microbiological and chemical parameters. Statistically, such pattern can hardly be expected if different bodies of water had been sampled. Colony-forming units, total number of microorganisms, biomass, number of cells actively metabolizing glucose and actual uptake rates of glucose and fructose followed a similar "diurnal" curve, showing increasing values during the day, maxima in the evening and decreasing values during the night. After $24 \mathrm{~h}$ of observation, the values obtained for most of the microbiological parameters were in the range measured the day before.

The inverse relationships between microbiological and organic chemical parameters (dissolved and particulate organic carbon; total free amino acids) indicate that microorganisms are responsible for the variations in organic matter. The strong variations in individual components of labile organic matter (amino acids, monosaccharides) did not reflect the variations in total DOC. The same had already been found during a comparative study of microbiological and chemical parameters in sandy beach sediments (Meyer-Reil et al., unpublished). Liberation and consumption of amino acids on the one hand and monosaccharides on the other followed different curve patterns. Whereas the POC concentration (approximately $2 \%$ of DOC) remained relatively constant during the observation period, the concentration of dissolved organic matter considerably decreased during the day. This was particulary true for the decrease in labile DOC (amino acids, monosaccharides). Such decrease was not compensated for by the relatively small increase during the night. Consequently, organic matter was consumed to a higher degree than supported by primary production. These observations suggest that the activity of heterotrophic microorganisms becomes quickly limited by the availability of decomposable organic matter, unless primary producers resupport the system.

The nearshore station in Kiel Fjord is heavily influenced by land and by ship traffic. Depending on wind and current, water bodies can change quickly (Lenz, 1977). In contrast to the stations at Kämpinge and in the south-eastern Baltic Sea, we certainly did not sample a uniform water body. The strong variations observed in the number of colony-forming units, concentration and actual uptake rates of glucose and fructose, and concentration of dissolved inorganic nutrients obviously reflect water-body changes. There was no indication of a distinct pattern common to variations in microbiological and/or chemical parameters.

The significant interrelationships (Spearman rank correlation analysis) between phosphate and both number of colony-forming units $(0.05 \%$ level) and actual uptake rates of glucose $(0.01 \%$ level) are obviously indirect. Water bodies with higher concentrations of phosphate may be expected to contain higher concentrations of organic nutrients, thus increasing uptake activity and number of colony-forming units. This assumption is supported by the significant correlation $(0.05 \%$ level) between ammonia and fructose. Working in the same area, Gocke (1975) found corresponding interrelationships between number of colonyforming units, maximum uptake velocity of glucose and ammonia, and phosphate (Pearson correlation coefficients).

For the two stations at which a uniform, individual water body was sampled at short intervals, distinct 
patterns of fluctuation or rhythms of microbiological and chemical parameters could be demonstrated (stations at Kämpinge and in the south-eastern Baltic Sea). The patterns are different, obviously reflecting different ecological situations. However, distinct fluctuation patterns may have been masked if changing water bodies were sampled (station in Kiel Fjord). While some general features of the fluctuation patterns could be illustrated in this study, their causes remain unclear. The data presented are too sparse to be interpreted in terms of "diumal" fluctuations. However, the probability is indicated that the material cycle in natural waters is governed by fluctuations or even rhythms of microbiological and/or chemical parameters.

The literature on this topic is very limited: it is difficult to follow uniform, individual bodies of water over prolonged periods of time and to process frequent sample series. Determining acid phosphatase in fresh water at different times during the day, Overbeck and Babenzien (1964) found no indication of a "diurnal" rhythm. Tanaka et al. (1974), analysing the vertical distribution of bacteria (direct counts) in Lake Biwa, demonstrated pronounced differences in the number of cells between samples taken at three different times during the day. However, there is no information on the unifarmity of the water bodies sampled. Furthermore, the low sampling frequency did not allow detailed interpretation.

The problems outlined above and the limited information available in the literature stress the need for further investigations on short-term dynamics of microbiological and chemical parameters.

Acknowledgements. We are indebted to K. Grasshoff for determination of dissolved inorganic nutrients and to $\mathrm{K}$. Kremling for determining the particulate organic carbon. We further wish to thank W. Schmidt and $H$. Tiedge for valuable assistance.

\section{LITERATURE CITED}

Dawson, R. and Pritchard, R. G. (1978). The determination of $\alpha$-amino acids in sea water using a fluorimetric analyser. Mar. Chem., 6, 27-40.

Gocke, K. (1975). Studies on short-term variations of heterotrophic activity in the Kiel Fjord. Mar. Biol., 33, 49-55.

Grasshoff, K. (1976). Methods of Seawater Analysis, Verlag Chemie, Weinheim, New York

Gunkel, W. (1970). Light: bacteria, fungi and blue-green algae. In O. Kinne (Ed.), Marine Ecology, Vol. I, Environmental Factors, Part 1. Wiley, London. pp. 103-124

Gunkel, W. (1972). Organic substances: bacteria, fungi and blue-green algae. In O. Kinne (Ed.), Marine Ecology, Vol.
I, Environmental Factors, Part 3. Wiley, London. pp. $1535-1549$.

Josefsson, B. O. (1970). Determination of soluble carbohydrates in seawater by partition chromatography after desalting by ion-exchange membrane electrodialysis. Analytica chim. Acta, 52, 65-73.

Kinne, O. (Ed.) (1978). Marine Ecology, Vol. IV, Dynamics, Wiley, Chichester.

Lenz, J. (1977). Hydrographic conditions. In G. Rheinheimer (Ed.), Microbial Ecology of a Brackish Water Environment. Springer-Verlag, Berlin. pp. 12-25.

MacLeod, R. A. (1971). Salinity: bacteria, fungi and bluegreen algae. In O. Kinne (Ed.), Marine Ecology, Vol. I, Environmental Factors, Part 2. Wiley, London. pp. 689-703.

Meyer-Reil, L.-A. (1977). Bacterial growth rates and biomass production. In G. Rheinheimer (Ed.), Microbial Ecology of a Brackish Water Environment. Springer-Verlag, Berlin. pp. 223-236.

Meyer-Reil, L.-A. (1978a). Autoradiography and epifluorescence microscopy combined for the determination of number and spectrum of actively metabolizing bacteria in natural waters. Appl. environ. Microbiol., 36, 506-512

Meyer-Reil, L.-A. (1978b). Uptake of glucose by bacteria in the sediment. Mar. Biol., 44, 293-298.

Meyer-Reil, L.-A., Dawson, R., Liebezeit, G. and Tiedge, H. (1978). Fluctuations and interactions of bacterial activity in sandy beach sediments and overlying waters. Mar. Biol., 48, 161-171.

Meyer-Reil, L.-A., Bölter, M., Dawson, R., Liebezeit, G., Szwerinski, $H$. and Wolter, $K$. (unpublished). Interrelationships between microbiological and chemical parameters of sandy beach sediments.

Morita, R. Y (1972). Pressure: bacteria, fungi and blue-green algae. In O. Kinne (Ed.), Marine Ecology, Vol. I, Environmental Factors, Part 3. Wiley, London. pp. 1361-1388.

Oppenheimer, C. H. (1970). Temperature: bacteria, fungi and blue-green algae. In O. Kinne (Ed.), Marine Ecology, Vol. I, Environmental Factors, Part 1 Wiley, London. pp. $347-361$.

Overbeck, J. and Babenzien, H.-D. (1964). Uber den Nachweis von freien Enzymen im Gewässer. Arch. Hydrobiol., $60,107-114$.

Rheinheimer, G. (1971). Turbidity: bacteria, fungi and bluegreen algae. In O. Kinne (Ed.), Marine Ecology, Vol. I, Environmental Factors, Part 2. Wiley, London. pp. $1167-1175$

Rheinheimer, G. (1972). Dissolved gases: bacteria, fungi and blue-green algae. In O. Kinne (Ed.), Marine Ecology, Vol. I, Environmental Factors, Part. 3. Wiley, London. pp. $1459-1469$

Sachs, L. (1974). Angewandte Statistik, Springer-Verlag, Berlin.

Sorokin, Y I. (1978). Decomposition of organic matter and nutrient regeneration. In O. Kinne (Ed.), Marine Ecology, Vol. IV, Dynamics. Wiley, Chichester. pp. 501-616.

Tanaka, N., Nakanishi, $M$ and Kadota, H. (1974). Nutritional interrelation between bacteria and phytoplankton in a pelagic ecosystem. In R. R. Colwell and R. Y. Morita (Eds), Effect of the Ocean Environment on Microbial Activities. University Park Press, Baltimore. pp. 495-509.

ZoBell, C. E. (1972). Substratum: bacteria, fungi and bluegreen algae. In O. Kinne (Ed.), Marine Ecology, Vol. I, Environmental Factors, Part 3. Wiley, London. pp. $1251-1322$ 